\title{
Evaluation of the Technical and Economic Impacts of High-Density Broiler Production in an Integrated System
}

\section{author(s)}

Schmidt GS

Researcher at Embrapa Suínos e Aves

Mail Address

Gilberto Silber Schmidt

Embrapa Suínos e Aves

BR 153 km 110, CP. 21

89.700-000. Concórdia, SC, Brazil

E-mail: schmidt@cnpsa.embrapa.br

\section{Keywords}

Broilers, density, economic indices, integration, performance parameters.

\section{ABSTRACT}

This study included 35 farmers contracted by a broiler integrator company. Each farmer owned an average of seven poultry houses, housing six flocks per year per farmer, summing up 4.0 million broilers housed. Live performance was evaluated in flocks housed in three densities (D1<12, 12<D2<14, and D3>14 birds/m2), and included the following parameters: market age (MA), average flock weight (AFW), average daily gain (DWG), feed conversion ratio (FCR), livability (LB), production efficiency index (PEI) and carcass yield/m2 (CY). Production costs and gross margin were calculated with birds housed at two densities ( $11.5<\mathrm{D} 4<12.4$ and $14.5<\mathrm{D} 5<15.5 \mathrm{birds} / \mathrm{m} 2)$, standardizing MA to 44 days. The economic evaluation included 15 farmers and 1.0 million broilers housed. The average densities obtained for D1, D2, D3, D4, and D5 were $11.80,13.15,15.00,12.02$, and 14.98 birds/m2, respectively. Density effect was significant on most parameters, with D1 producing the best results in AFW, DWG, FCR, LB, and PEI, whereas D2 and D3 produced different results only in FCR. Despite the reduction in animal performance, carcass yield $/ \mathrm{m} 2$ linearly increased with density. The economic analyses showed higher production costs, despite the higher margin for D5. The greatest impact was the reduction in farmer's compensation (19.68\%) per bird housed. From the farmer's perspective, the $5 \%$ increase in compensation should be enough to cover the investment required to supply the requirements of higher densities.

\section{INTRODUCTION}

The pressure of the consumer market for the reduction of chicken prices has led poultry companies to apply strategies to decrease production costs in an attempt to maximize performance with the maximum economic return. Higher bird densities have been used to reduce particularly labor costs and investments in facilities and transport logistics (Lana, 2001). Nevertheless, bird density has been often increased without the required adjustments in facilities, equipment, management, and nutrition.

Despite the controversial literature results, mainly due to differences in environmental conditions, management, nutrition, and flock health status, on the optimal density to obtain the best revenues in broiler production, most studies show a linear decrease in live performance as bird density increases (Hellmeinster et al., 1998, Feddes et al., 2002, Mendes et al., 2002; Fascina et al., 2006); however, higher meat production $/ \mathrm{m}^{2}$ and profitability were also demonstrated (Mendes et al., 2002).

Meat production $/ \mathrm{m}^{2}$ and production cost per housed broiler significantly increase with density, as well as profitability $/ \mathrm{m}^{2}$ (Mendes et al., 2002; Goldflus et al., 1997; Stringhini et al., 1997). In order to 
understand this apparent paradox, it is necessary to determined which cost components are influenced by high bird density. Considering that a company has an idle processing capacity, higher densities reduce part of the operational cost and the costs with the contracted producers due to the increase in volume. On the other hand, the contracted farmer needs to invest more to provide conditions that allow housing more birds per surface area. Therefore, cost-benefit ratio needs to be evaluated at the farm level.

This study aimed at estimating the effect of bird density on the technical and economic parameters of an integration system.

\section{MATERIAL AND METHODS}

This study was carried out in an integrator company with a slaughter capacity of 120.000 broilers/day during 12 months. The study involved 35 contracted farmers, with 7 broilers houses in average, and housing an average of 6 flocks at the time of the study, summing up 4 million day-old chicks housed. All houses were equipped with tunnel ventilation, automatic feeders, nipple $(60 \%)$ or bell $(40 \%)$ drinkers, foggers, fans, and an average available area of 1,500 $\mathrm{m}^{2}$.

During the study period, different densities were used among and within farms, and ranged from 11 to $16 \mathrm{birds} / \mathrm{m}^{2}$. In order to evaluated the effect of bird density on live performance parameters, flocks were housed in three densities: below 12 (D1), between 12 and 14 (D2), and more than 14 (D3) birds $/ \mathrm{m}^{2}$. The following performance parameters were evaluated: market age (MA), mean flock weight (AFW), average daily weight gain (DWG), feed conversion ratio (FCR), livability (LB), production efficiency index (PEI) and carcass weight in $\mathrm{kg} / \mathrm{m}^{2}(\mathrm{CY})$.

In order to simulate the economic impact, performance parameters of flocks with densities ranging between 11.5 and 12.5 (D4), and between 14.5 and 15.5 (D5) birds $/ \mathrm{m}^{2}$, and market age of 44 days were used. These restrictions reduced the number of studied contracted farmers to 15, with an average of 2 flocks and 1 million chicks housed.

Performance and economic parameters obtained at both densities were used to estimate production capacity and cost of flocks raised at 12 and 15 birds/ $\mathrm{m}^{2}$, considering a broiler house with 1,500 $\mathrm{m}^{2}$ available area. Production cost was estimated considering dayold chick price, contracted farmer compensation, feed price, and operational costs (inputs, transport, technical services, and taxes).

Farmer's gross margin was calculated based on the company's compensation table, which takes into account production efficiency index (PEI) and average broiler price. For this simulation, we considered the average live broiler price in São Paulo stock exchange (R\$ 1.40).

In order to evaluate the effect of density on performance, 400 flocks were used per density, whereas the economic evaluation took into account only 100 flocks per density.

Data were analyzed using SAS (1996) statistical package, and treatment means were compared by the test of Tukey.

\section{RESULTS AND DISCUSSION}

The estimated means and regression curves of the studies parameters, according to the different bird densities, are shown in Table 1.

Mean densities obtained for D1, D2, and D3 were $11.80,13.15$, and 15.00 birds $/ \mathrm{m}^{2}$, respectively. The effect if bird density was significant for most performance parameters, with D1 promoting higher AFW, DWG, FCR, LB, and PEI, whereas D2 and D3 resulted only in different FCR. These results confirm a linear reduction of performance levels, which is consistent with most studies found in literature (Feddes et al., 2002, Hellmeinster et al., 1996; Mendes et al., 2002; Fascina et al., 2006). However, meat production

\begin{tabular}{|c|c|c|c|c|}
\hline \multirow[t]{2}{*}{ Parameters } & \multirow[t]{2}{*}{ Regression equation } & \multicolumn{3}{|c|}{ Bird density } \\
\hline & & D1 & D2 & D3 \\
\hline Density $\left(\mathrm{birds} / \mathrm{m}^{2}\right)^{*}$ & - & 11.80 & 13.15 & 15.00 \\
\hline Market age (days) & - & $44.52^{\mathrm{a}}$ & $44.91^{\mathrm{a}}$ & $45.80^{\circ}$ \\
\hline Flock weight (g) & $A F W=2.484-17.5 *$ Dens & $2.306^{\mathrm{a}}$ & $2.227^{b}$ & $2.229^{b}$ \\
\hline Daily weight gain (g) & DWG $=54.03-0.70 *$ Dens & $51.79^{a}$ & $49.59^{b}$ & $48.67^{b}$ \\
\hline Feed conversion ratio & $F C R=1.53+0.03 *$ Dens & $1.88^{a}$ & $1.93^{b}$ & $1.98^{c}$ \\
\hline Livability (\%) & - & $97.59^{a}$ & $96.23^{a}$ & $96.33^{\circ}$ \\
\hline Efficiency index & $\mathrm{PEI}=333.0-5.8 *$ Dens & $271^{a}$ & $253^{b}$ & $250^{b}$ \\
\hline Carcass yield $\mathrm{kg} / \mathrm{m}^{2}$ & $C Y=25.12+0.81 *$ Dens & $26.55^{c}$ & $28.18^{b}$ & $32.20^{\circ}$ \\
\hline
\end{tabular}

Means followed by the different letters in the same row are significantly different $(P<0.01)$, * Mean values of the evaluated flocks. 
$\left(\mathrm{kg} / \mathrm{m}^{2}\right)$ linearly incresed with bird density, in agreement with the findings of Mendes et al. (2002), Goldflus et al. (1997), and Stringhini et al. (1997).

The increase in density in $1.0 \mathrm{bird} / \mathrm{m}^{2}$ resulted in worse FCR and $C Y$, in 0.03 units and $0.81 \mathrm{~g}$, respectively, and reduced AFW, DWG, and PEI in $17.5 \mathrm{~g}$, $0.70 \mathrm{~g}$, and 5.8 units, respectively. PEl, which is used to evaluate the production efficiency of the company, and usually determines contracted farmer's compensation, was reduced in $8.4 \%$.

The performance parameters used to estimate economic effects, production capacity, production cost, and margin obtained for D1 and D2 are presented in Table 2. Similarly as to the results obtained in the first phase of analysis, performance parameters suffered a linear reduction as density increased. Farmer's compensation/bird housed was reduced in $16 \%$, but compensation per flock increased $5.0 \%$. from the contracted farmer's perspective, only D2 was beneficial, provided it is sufficient to pay the investment required to increase density from D1 to D2.

Density increase elevated broiler production cost in $2.3 \%$, reducing the gross margin per $\mathrm{kg}$ in $11.11 \%$ and per marketed bird in $11.25 \%$, but the gross margin/ $\mathrm{m}^{2}$ of broiler house in $10.8 \%$ (Table 2 ). Therefore, from the integrator company's standpoint, the use of high bird density had a positive effect on gross margin, despite the losses in live performance.

\begin{tabular}{|c|c|c|}
\hline \multirow[t]{2}{*}{ Parameters } & \multicolumn{2}{|c|}{ Bird density } \\
\hline & 12 & 15 \\
\hline \multicolumn{3}{|l|}{ Performance parameters } \\
\hline Flock weight (g) & $2,306^{a}$ & $2,229^{b}$ \\
\hline Livability (\%) & $97.59^{\mathrm{a}}$ & $96.33^{b}$ \\
\hline feed conversion ratio & $1.90^{\mathrm{a}}$ & $1.97^{b}$ \\
\hline Average density & 12.35 & 14.87 \\
\hline Production efficiency index (PEI) & $271^{\mathrm{a}}$ & $250^{b}$ \\
\hline \multicolumn{3}{|l|}{ Economic indices } \\
\hline Farmer's compensation/bh & $R \$ 0.25$ & $R \$ 0.21$ \\
\hline Total farmer's compensation & $R \$ 4,500.00$ & $R \$ 4,725.00$ \\
\hline Production cost $/ \mathrm{kg}$ broiler & $R \$ 1.157$ & $\mathrm{R} \$ 1.184$ \\
\hline \multicolumn{3}{|l|}{ Estimated parameters } \\
\hline Birds housed & 18,000 & 22,500 \\
\hline Birds slaughtered & 17,566 & 21,674 \\
\hline Produced kg & 40,507 & 49,829 \\
\hline Total cost & $R \$ 46,867.36$ & $R \$ 58,997.66$ \\
\hline Revenue & $R \$ 56,710.72$ & $R \$ 69,760.74$ \\
\hline Revenue - Cost & $R \$ 9,843.36$ & $R \$ 10.763 .09$ \\
\hline Margin $/ \mathrm{kg}$ & $R \$ 0.243$ & $R \$ 0.216$ \\
\hline Margin/bird & $R \$ 0.560$ & $\mathrm{R} \$ 0.497$ \\
\hline Margin $/ \mathrm{m}^{2}$ & $\mathrm{R} \$ 6.724$ & $\mathrm{R} \$ 7.449$ \\
\hline \multicolumn{3}{|l|}{ Cost distribution (\%) } \\
\hline Day-old chick & 16.16 & 16.07 \\
\hline Farmer & 8.89 & 7.14 \\
\hline Feed & 68.39 & 70.46 \\
\hline Operational cost & 6.47 & 6.33 \\
\hline
\end{tabular}

bh - bird housed.
The estimated contribution of the different cost component to the price of the $\mathrm{kg}$ of produced broilers indicates that, as density increases, the highest reduction is on farmer's compensation (19.68\%), followed by day-old chick cost (11.80\%).

Feed cost increased 3.0\%, due to the $5.3 \%$ increase in feed conversion ratio, which was 1.88 (D1) and 1.98 (D3). The lowest impact was on operational cost, which was reduced in $2.16 \%$. However, it must be considered that, in this simulation, operational cost was fixed, and did not take into account reductions caused lower logistics costs for technical service, and inputs, which would result in higher economic return to the integrator company.

\section{CONCLUSIONS}

Increasing bird density at rearing linearly reduced live performance, but increases meat production capacity $/ \mathrm{m}^{2}$ and net margin per flock housed.

The use of high bird density, from the integrator company perspective, depends on the reduction of the integration's operational costs, particularly of the contracted farmer's compensation per bird housed, which must be lower than the cost increased caused by worse live performance. An increase of $5 \%$ in farmer's compensation per flock should be sufficient to cover the investments required to fulfill the requirements of higher bird density.

\section{REFERENCES}

Fascina VB, Muniz EC, Guimarães EB, Carrijo AS. Diferentes densidades populacionais sobre o peso corporal e calos de patas em frangos de corte. Revista Brasileira de Ciência Avícola 2006; Supl 8:7.

Feddes JJR, Emmanuel EJ, Zuidhoft MJ. Broiler performance, body weight variance, feed and water intake, and carcass quality at different stocking densities. Poultry Science 2002;81(6):774-779.

Goldflus F, Ariki J, Kronka SN. et al. Efeito de diferentes densidades populacionais nas estações fria e quente do ano sobre o desempenho de frangos de corte. Revista da Sociedade Brasileira de Zootecnia 1997; 26(5):948-954.

Hellmeinster Filho P, Custódio RWS, Coelho AAD. et al. Desempenho de frangos criados em diferentes densidades. Revista da Sociedade Brasileira de Zootecnia 1998; 26(1):137-142.

Lana GRQ, Silva Junior GRQ, Valerio SR. et al. Efeito da densidade e de programas de alimentação sobre o desempenho de frangos de corte. Revista da Sociedade Brasileira de Zootecnia 2001; 304(4):1258-65. 
Mendes AA, Moreira J,Roça RO. et al. Efeito da taxa de lotação e nível de energia na dieta sobre o desempenho, rendimento de carcaça e análise econômica em frangos de corte. Revista Brasileira de Ciência Avícola 2002; Supl 4:4.

SAS Institute. Statistical analysis sistems user's guide: Stat. Version 6. $4^{\text {th }}$ ed Cary; 1996.

Stringhini JH, Ariki J, Café MB. et al. Níveis de proteína em frangos criados em duas densidades populacionais. Anais da Conferencia Apinco de Ciência e Tecnologia Avícola;1997; São Paulo, São Paulo. Brasil. Campinas:FACTA; 1997. p.24. 